\title{
Impact of COVID-19 on Food Systems and Rural Livelihoods in Zambia
}

\author{
COVID-19 Country Report - December 2020
}

Prepared by Chrispin Matenga and Munguzwe Hichaambwa

\section{Introduction}

To assess the impact of COVID-19 on local food systems and livelihoods, a total of 115 small-scale farming households (102 male- and 13 female-headed) were interviewed from five communities (Lilanda, Luanga (Mankanda), Masansa, Nshinso and Miloso (Tazara Corridor) surrounding the Mkushi Farm Block in the Central Province of Zambia between 30 September and 6 November 2020. The respondents were selected as a random sample, targeting 20-25 households per community or village. The small-scale farmers in these areas benefit from linkages with commercial farmers in the block.

\section{Context}

Zambia reported its first COVID-19 case on 18 March 2020. The government responded with a partial lockdown involving phased restrictions. Brief border closures and mandatory testing/ quarantine of truck drivers disrupted cross-border movement, which impacted the supply chain for important commodities, such as agricultural inputs and markets critical to smallholder producers. As of 29 October 2020, the government reported 16,325 COVID-19 confirmed cases and 348 deaths. ${ }^{1}$

\section{Health and disease}

All respondents declared adherence to COVID-19 guidelines. Only 4\% declared COVID-19 symptoms in their households, while $11 \%$ of men and $23 \%$ women reported knowing someone with symptoms in their village. Almost half (49\%) of respondents reported having heard of confirmed COVID-19 cases in their areas. Nearly all (97\%) respondents were still able to access healthcare at the village clinic or elsewhere.

\section{Availability of services for agricultural production}

COVID-19 has adversely affected availability of services for agricultural production. Respondents reported decreases

\section{Key findings}

- Following the COVID-19 crisis, $47 \%$ of respondents reported a decrease in participation in farming activities and business (85\%) as labour, key agricultural services availability and access to markets decreased. Costs of farm labour and transportation of produce increased.

- Since the start of the pandemic, availability of key foods such as milk, milk products and grains decreased (43\% to $59 \%)$, while food prices increased (76\% to $97 \%$ ). This compromised household food and nutrition security.

- COVID-19 restrictions reduced movements within and outside the communities (100\%) and the number of traders coming to the villages to purchase produce (85\%).

in availability of agricultural land to rent (50\%), farm inputs (50\%), agricultural extension services (56\%), loans/credit (59\%), contractual arrangements for cash crops (54\%), and concessionary loans (62\%). Prices for farm inputs, tillage services and agricultural land rental have significantly increased (90\%, 89\% and $76 \%$, respectively).

"Because of fear of COVID, most farmers are selling just locally so it's not good because prices (of farm produce) are really low... while inputs are expensive." - Agricultural Camp Officer, Nshinso Community

"Cross-border trade was negatively affected. For example, Kasumbalesa is the huge market for farmers here in Mkushi, especially tomatoes, and when there were restrictions on movement across borders, farmers could not take their products there." - Area local government councillor, Masansa Community

Figure 1: Availability of agricultural production services

Contractual arrangements for main cash crop(s)

Availability of agricultural extension services

Availability of tillage services

Farm input prices

Availability of farm inputs

Agricultural land rental prices

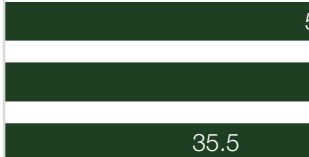

53.9 32.9

\section{3} 36.6

\begin{tabular}{|c|c|c|c|}
\hline $7 \quad 8.7$ & \multicolumn{3}{|c|}{89.6} \\
\hline & 50.4 & 35.7 & 13.9 \\
\hline
\end{tabular}

0 


\section{Responses to the threat of COVID-19}

Due to official COVID-19 guidelines, over 90\% of respondents reduced movements within and outside their villages. After schools were closed due to the crisis, children were left to work at home more (61\% and $64 \%$ for girls and boys, respectively). They also did more housework (76\% and 68\%), more farm work (41\% and 64\%), and some paid work away from home (5\% and 7\%). Some children were reported to be sitting idle (17\% boys and $13 \%$ girls). Care responsibilities increased markedly for sick and elderly people, children, and other family and friends after the start of the pandemic, while cooking fuel and/or water collection also increased (84\%). Respondents said that most COVID-19 assistance was received from government (33\%) and local village organisations (12\%), while a smaller number received support from other external organisations (7\%), religious organisations (6\%) and family/friends (4\%).

\section{Food and nutrition security}

Food availability, except for dark green leafy vegetables, generally decreased, particularly for milk and milk products (60\%). With reduced availability, food prices generally increased. After the start of the pandemic, the majority of respondents reported worrying about not having enough food to eat (85\%). Many described an inability to eat healthy/nutritious food (70\%), having to skip a meal (67\%), eating less than they should (70\%), running out of food (51\%), and spending the whole day without eating (40\%) because of a lack of money. Nearly three out of five (58\%) reported not having enough food to meet their families' needs. The cost of living was stated to have increased for many households (84\%).
Figure 2: Changes in food availability

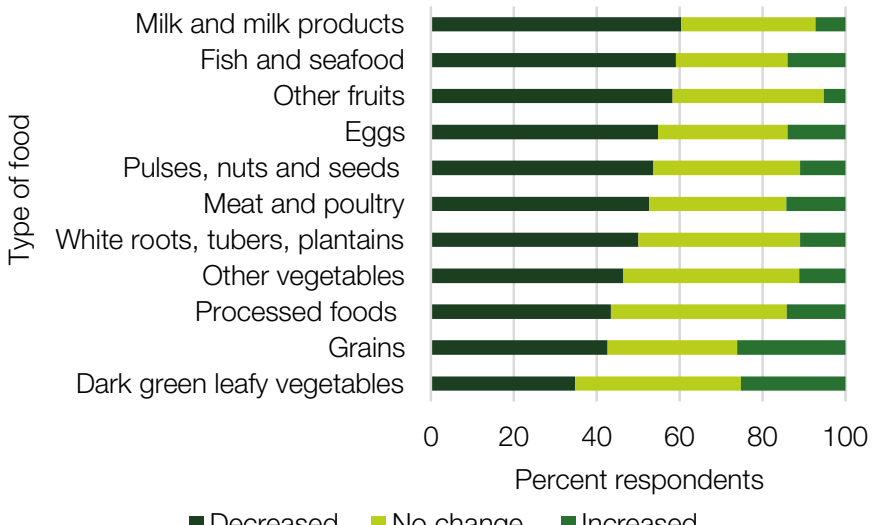

-Decreased No change $\square$ Increased

\section{Farming, labour and marketing}

Communities reduced participation in farming activities, as reported by $47 \%$ of respondents. The decrease in participation in business or household enterprises was even more severe; all female-headed households in our sample reported a decline. Roughly half of respondents stated they were able to access off-farm work within their villages, however only one in five were able to do so outside their villages (20\%). Ability to hire labour was reported by $63 \%$ but costs of casual and seasonal labour increased (78\%). Ability to sell farm produce in all markets largely decreased, as reported by $65 \%$ to $82 \%$ of the respondents. Ability to hire transport to agricultural markets was reported by more than half the respondents (56\%) but costs significantly increased (96\%). The number of buyers coming to the villages largely decreased (86\%), which led to a drop in demand for agricultural produce. Respondents reported handling business transactions using cash (93\%), electronic transfer (72\%) and bartering (50\%).

Figure 3: Changes in ability to sell farm produce

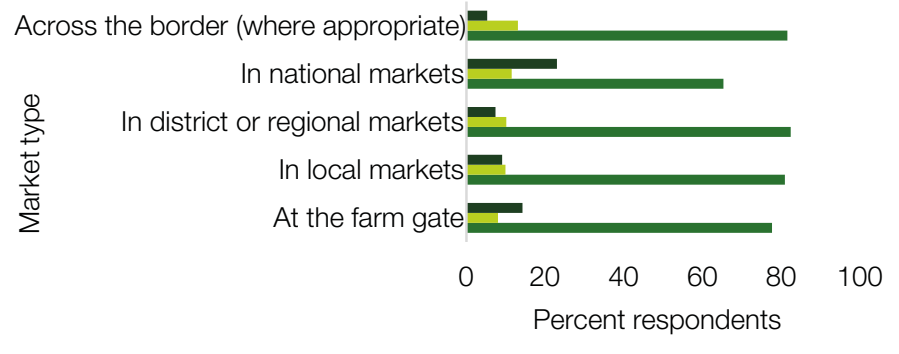

- Increased No change Decreased

Matenga, C. and Hichaambwa, M. (2020) Impact of COVID-19 on Food Systems and Rural Livelihoods: Zambia.

Round 1 - December 2020, APRA COVID-19 Country Report, Brighton: Future Agricultures Consortium
(C) APRA 2020
ISBN: 978-1-78118-785-2
DOI: 10.19088/APRA.2021.006

This is an Open Access report distributed under the terms of the Creative Commons Attribution Non Commercial No Derivatives 4.0 International licence (CC BY-NC-ND), which permits use and distribution in any medium, provided the original authors and source are credited, the work is not used for commercial purposes, and no modifications or adaptations are made.

If you use the work, we ask that you reference the APRA website (www.future-agricultures.org/apra) and send a copy of the work or a link to its use online to the following address for our archive: APRA, Future Agricultures, University of Sussex, Brighton BN1 9RE, UK (apra@ids.ac.uk) 